\title{
Biblioteca, memória e identidade social ${ }^{1}$
}

\section{Fabrício José Nascimento da Silveira}

\author{
Bibliotecário. Doutorando em Ciência da \\ Informação pelo Programa de Pós-Graduação em \\ Ciência da Informação da Escola de Ciência da \\ Informação da Universidade Federal de Minas \\ Gerais - PPGCI/UFMG.
}

Este artigo tem por objetivo refletir sobre a seguinte questão: qual a participação das bibliotecas púbicas no processo de constituição, preservação e difusão de referenciais identitários na contemporaneidade? Para tanto, aborda-se, em um primeiro momento, as diversas nuances que perpassam e caracterizam a questão do pertencimento cultural na pós-modernidade para, em seguida, analisar as relações que se instituem entre as noções de memória e identidade social. Por fim, discorre-se sobre as possibilidades de participação das bibliotecas públicas, enquanto "lugares de memória", nos processos de constituição, preservação e difusão de discursos identitários na contemporaneidade.

Palavras-chave: Biblioteca - memória social; Biblioteca identidade; Memória - discurso identitário; Lugares de Memória.

\section{Library, memory and social identity}

The aim of this essay is to discuss the following question: what is the role of public libraries in the process of constitution, preservation and diffusion of identity referentials in the contemporary world? Firstly, we are approaching the various aspects of cultural belonging in post modernity and then we are analyzing the relation between the concepts of memory and social identity. Eventually, we are discussing the possible contribution of public libraries, considered here as "places of memory", to the process of constitution, preservation and diffusion of identity speeches in post modernity

\footnotetext{
${ }^{1}$ Este artigo é uma síntese do primeiro capítulo de minha dissertação de mestrado defendida junto ao Programa de PósGraduação em Ciência da Informação, da Escola de Ciência da Informação da Universidade Federal de Minas Gerais ECI/UFMG, em setembro de 2007, sob orientação da Profa. Dra. Alcenir Soares dos Reis, a quem sou ligado por afeição, solidariedade intelectual e profunda gratidão. Ressaltamos que a referência completa da mesma encontra-se citada nas fontes bibliográficas do presente texto.
} 
Keywords: Library - social memory; Library - identity; Memory

- identity speech; Place of Memory.

Recebido em 14.05.2010

Aceito em 18.10.2010

\section{Introdução}

As reflexões que ora apresentamos têm sua gênese ligada à constatação de que, a partir do início da década de 1960, conceitos como memória, discurso identitário e identidade social (seja esta individual ou coletiva) se tornaram aportes indispensáveis para explicar as relações humanas na contemporaneidade. Quadro de referências que emerge pautado pelo advento da globalização e por uma profunda transformação das noções de tempo e espaço, bem como pela sensação de que as ações sociais do homem moderno não mais se instituem de forma tão estáveis como outrora. Percepções que, por sua vez, promovem o aparecimento de um intenso debate sobre o que é pertencer culturalmente a uma coletividade e como esse sentimento nos define, enquanto sujeitos socialmente localizados e integrados a um dado contexto espaço-temporal.

Pressupostos que nos ajudam a apreender que, nesse novo momento histórico, possuir uma identidade não mais significa inserir-se primordialmente em um núcleo imutável e atemporal que liga o passado ao presente, e este ao futuro, em uma linha ininterrupta forjada pelo apego à tradição ou por uma suposta fidelidade às origens. É, antes, a consciência e a possibilidade de se abarcar, o mais amplamente possível, o jogo de semelhanças e diferenças presentes nas culturas do mundo inteiro.

No entanto, de acordo com França (2002), faz-se necessário notar que a ideia de identidade é um construto que tem como elemento de sustentação discursos, objetos e práticas simbólicas que nos posicionam no mundo e que dizem nosso lugar em relação ao outro (outros pontos de referência, outros lugares). Ao fazer isso, a identidade também marca e estabelece uma posição, o lugar que efetivamente construímos e no qual nos inserimos. Ela se constrói, assim, nessa interseção entre discursos que nos posicionam e o nosso movimento de nos posicionarmos enquanto sujeitos no mundo. Discursos que, por sua vez, são produzidos e disseminados através de repertórios simbólicos demasiadamente amplos, que em momento algum podem ser interpretados como se possuíssem apenas um sentido. Ou seja, independente se originário do seio familiar, das reuniões de sindicatos, das práticas escolares ou de manifestações político-religiosas, é o movimento de apropriação desses repertórios simbólicos que possibilita ao sujeito e mesmo a uma coletividade inteira construir e consolidar seus vínculos identitários.

Talvez sejam essas as razões que conferiram acentuado relevo a uma série de atividades ligadas à preservação e à difusão de signos e práticas mnemônicas nos últimos 50 (cinquenta) anos. Argumento que se vê reforçado pela análise dos eventos que levaram à proliferação, ainda no período acima compreendido, dos "lugares de memória". Espaços que surgem para nos lembrar que a memória, por mais vigorosa que seja, é frágil demais para reter voluntariamente a totalidade das experiências humanas, sendo necessário, pois, criar arquivos; museus; monumentos; organizar celebrações públicas e pronunciar elogios funerários como recurso para se manter viva a história e a cultura de todo um tecido social. Os lugares de memória se configuram assim, como instâncias físicas ou virtuais que se organizam para servir de apoio à salvaguarda da materialidade simbólica concebida como elemento de representação coletiva. 
É o que acontece também com as bibliotecas, especialmente com as públicas, cuja função social está diretamente ligada à missão de preservar, organizar e disseminar os elementos culturais e os insumos de conhecimentos concebidos por nosso fazer racional. Ou seja, enquanto "lugares de memória", as bibliotecas tendem a reafirmar os saberes e a torná-los móveis, traduzíveis, permutáveis, enfim, tentam dar sentido ao saber e a fazer com que o mesmo se torne um instrumento de reafirmação da "identidade" individual ou coletiva humana.

Essa característica foi instituída desde quando o acúmulo e a transmissão de elementos culturais passaram a fazer parte do nosso cotidiano. As primeiras bibliotecas se formaram em paralelo à invenção da escrita, momento no qual o homem passa a gravar em matéria estável a substância essencial daquilo que era narrado, daquele conteúdo que se conservava e se transmitia oralmente, através das práticas de narração e rememoração. O que implica ressaltar que à memória biológica, que pertence à espécie e à memória cerebral, que pertence ao indivíduo, acrescentou-se a biblioteca como memória coletiva das experiências existenciais, científicas e culturais do lugar onde se insere. Inscrita sob a forma de documento, essa memória requer sua reunião, organização e meios específicos para sua disseminação, tendo-se em vista um amplo uso por parte de todos aqueles que contribuem para sua formação.

Nesse sentido, embora se apresentem como lugares mistos e, em ampla medida, perpassados por tensões ideológicas, paradoxos e contradições, os mais de 6000 (seis mil) anos de história das bibliotecas lhes conferem o status de espaços privilegiados do saber, nos quais o patrimônio, a memória coletiva e a herança cultural dos homens encontram solo profícuo para edificarem as bases onde seus vínculos identitários se constituem, se nutrem e se valorizam. Ou seja, captar, conservar, preservar e compartilhar o conhecimento do mundo e de nós mesmos são alguns dos poderes (e perigos) que as bibliotecas nos oferecem.

Sendo assim, propomo-nos a discutir mais detalhadamente os pressupostos teóricos e os argumentos históricos acima apresentados, refletindo sobre a seguinte questão: qual a participação das bibliotecas púbicas no processo de constituição, preservação e difusão de referenciais identitários na contemporaneidade?

Para tanto, buscar-se-á evidenciar, em um primeiro momento, as diversas nuances que caracterizam a questão do pertencimento cultural na pósmodernidade para, em seguida, analisar as relações que se instauram entre as noções de memória e identidade social. Por fim, discorrer-se-á sobre as possibilidades de participação das bibliotecas públicas, enquanto "lugares de memória", nos processos de constituição, preservação e difusão de discursos identitários na contemporaneidade.

\section{Discurso identitário e pertencimento cultural na pós- modernidade}

Todo aquele que tencione discutir a questão da identidade e do pertencimento cultural na contemporaneidade deve iniciar sua empreitada se valendo do seguinte indício: talvez a marca mais eminente da condição pósmoderna seja a fragmentação. Isto porque, se até o advento da modernidade o 
homem era capaz de definir e localizar suas ações a partir de referenciais políticos e sócio-culturais estáveis, as mudanças estruturais oriundas da globalização e da distorção das noções de tempo e espaço imprimem novas configurações para as muitas esferas de sociabilidade com as quais passa a interagir. Característica que se torna um indicativo de que "as velhas identidades, que por tanto tempo estabilizaram a vida social, estão em declínio, fazendo surgir novas identidades e fragmentando o indivíduo moderno, até aqui visto como um sujeito unificado" (HALL, 2001, p. 7).

Com isso, se a definição básica de identidade vinculava-se à busca das origens; das semelhanças; dos substratos comuns; daquilo que, por baixo das diferenças, do movimento, das mudanças costura e mantém a unidade, a contemporaneidade passa a designá-la como um discurso em permanente processo de elaboração. Melhor dizendo, como uma produção que nunca se completa, formada e transformada no interior das representações ${ }^{2}$. Representações que, por sua vez, se forjam através do prisma da multiplicidade, da urdidura dos diversos discursos e práticas simbólicas que nos posicionam no mundo, que dizem nosso lugar em relação ao outro - outros pontos de referência, outros lugares.

Formulação teórica que nos permite salientar que o conceito identidade está diretamente vinculado à ideia de projeto, de algo que se encontra sempre em construção, distanciando-se, pois, da noção de repertório imagético que circunscreve o sujeito em torno de referenciais simbólicos supostamente estáveis, homogêneos, coesos e unificados. Portanto, enquanto construto estruturado discursiva e relacionalmente, o conceito identidade não está assentado apenas na identificação das semelhanças, dos compartilhamentos, visto trazer incutido, nesse mesmo movimento, a construção da diferença, da distinção. Em virtude disso, tentar idealizar um discurso identitário único, coeso e completo em si mesmo se torna uma fantasia, posto que o sujeito, através de seus posicionamentos, assume identidades múltiplas nos diversos momentos e espaços onde sua história de vida adquire sentido e encontra ressonância.

Isso acontece porque o cenário contemporâneo é caracterizado por rápidas e permanentes transformações que instituem um movimento de "distanciamento da idéia sociológica clássica de "sociedade" como um sistema bem delimitado e sua substituição por uma perspectiva que se concentra na forma como a vida social está ordenada ao longo do tempo e do espaço" (GIDDENS, 1990, p. 64 apud HALL, 2001, p. 67-68). Ou seja, neste novo momento histórico, pautado

\footnotetext{
${ }^{2}$ De acordo com as proposições do artigo, o termo representações pode ser definido como: forma de conhecimento socialmente elaborada e uma realidade comum a um conjunto social. Embora muitas vezes interpretada como saber de senso comum ou ainda saber ingênuo, natural, essa forma de conhecimento é diferenciada, entre outras, do conhecimento científico. Entretanto, é tida como um objeto de estudo tão legítimo quanto este, devido à sua importância na vida social e à elucidação possibilitadora dos processos cognitivos e das interações sociais. Neste sentido, enquanto sistemas de interpretação que regem nossa relação com o mundo e com os outros, as representações orientam e organizam as condutas e as interações sociais, da mesma forma que intervêm em processos variados, tais como a difusão e a assimilação dos conhecimentos, o desenvolvimento individual e coletivo, a definição das identidades pessoais e sociais, a expressão dos grupos e as transformações culturais. Em suma, enquanto fenômenos sociais, as representações envolvem a pertença social dos indivíduos com as implicações afetivas e normativas, com as interiorizações de experiências, práticas, modelos de conduta e pensamentos, socialmente inculcados ou transmitidos durante os processos de interação social, que a ela estão ligados. São, pois, produto e processo de uma atividade de apropriação da realidade exterior ao pensamento e de elaboração psicológica e social da realidade.
} 
pela dinâmica da globalização das economias; pela transgressão e enfraquecimento das fronteiras nacionais; pelo progresso e expansão das tecnologias da informação e da comunicação; pelo questionamento dos centros hegemônicos e entrada em cena da "periferia" e pela intensificação do fenômeno da hibridização cultural, assistimos:

[...] a um debate teórico sobre o fraturamento da identidade individual, em que a concepção de um indivíduo centrado, unificado, racional, dotado de um núcleo interior estável e permanente (o 'sujeito iluminista') é substituída pela noção de um novo sujeito (o 'sujeito pós-moderno') - fragmentado, dotado de identidades múltiplas e contraditórias, resultado das mudanças estruturais, institucionais e de valores da sociedade contemporânea. (GUIMARÃES et al., 2002, p. 9).

Estabelecendo uma interlocução com o autor acima citado, percebemos que a formulação de um discurso identitário está diretamente relacionada com os recursos utilizados pelos sujeitos sociais para se posicionarem no universo das práticas culturais ${ }^{3}$ através das quais vivenciam, experimentam ${ }^{4}$ o mundo. Razão pela qual enfatizamos que só é possível falar em discurso identitário se os matizes que o definem forem concebidos como amálgamas provenientes do entrelaçamento dos diversos olhares interpretativos que emergem no seio de referenciais simbólicos demasiadamente amplos, que em momento algum devem ser interpretados como se possuíssem apenas um sentido. Defendemos isso por que:

Os seres humanos são seres interpretativos, instituidores de sentido. A ação social é significativa tanto para aqueles que a praticam quanto para os que a observam: não em si mesma, mas em razão dos muitos e variados sistemas de significado que os seres humanos utilizam para definir o que significam as coisas e para codificar, organizar e regular sua conduta uns em relação aos outros. Estes sistemas ou códigos de significado dão sentido às nossas ações. Eles nos permitem interpretar significativamente as ações alheias. Tomados em seu conjunto, eles constituem nossas "culturas". Contribuem para assegurar que toda ação social é "cultural", que todas as práticas sociais expressam ou

\footnotetext{
${ }^{3}$ No escopo deste trabalho podemos definir práticas culturais como as várias manifestações simbólicas que permitem a cada sujeito imprimir uma marca interpretativa ao mundo que o cerca, atuando conscientemente na tentativa de instituir seus próprios lugares de representação para as inúmeras esferas que compõem sua vida individual ou coletiva. Acreditamos, pois, que é através do acesso e da interpretação das práticas culturais que o homem se constrói enquanto sujeito histórico.

${ }^{4}$ De acordo com França (2002; p. 34-38), experimentar o mundo significa apropriar-se de um determinado referencial simbólico e constituí-lo como nosso e, neste mesmo movimento, também nos constituirmos enquanto sujeitos no mundo. Essa noção de experiência possui, portanto, dimensões práticas e sensíveis de conhecimento que articulam de forma definitiva essas duas categorias que são o homem e o mundo. A experiência de conhecer o mundo refere-se, pois, ao trabalho de encaixá-lo em quadros de sentido; significa apropriar-se simbolicamente do mundo.
} 
comunicam um significado $e$, neste sentido, são práticas de significação (HALL, 1997, p. 26).

Sendo assim, o que podemos apreender das pistas lançadas por Hall (1997) é que o processo de constituição das ações culturais humanas acaba por refletir menos o que nós somos (estado) e mais o que nos tornamos (processo). Ou seja, que é a partir das táticas e das estratégias ${ }^{5}$ que utilizamos para interiorizar, significar e exteriorizar um determinado referencial simbólico que nos definimos, enquanto sujeitos capazes de assimilar e transformar o mundo com o qual interagimos. O que equivale dizer que a identidade emerge, não tanto de um centro interior, de um eu verdadeiro e único, mas do diálogo entre os conceitos, definições e práticas que são representadas para nós pelos discursos de uma cultura e pelo nosso desejo (consciente ou inconsciente) de responder aos apelos feitos por esses significados, de sermos interpelados por eles, de assumirmos as posições de sujeito constituídas por nós e para nós. Sendo mais explícito:

O que denominamos "nossas identidades" poderia provavelmente ser melhor conceituado como as sedimentações através do tempo daquelas diferentes identificações ou posições que adotamos e procuramos "viver", como se viessem de dentro, mas que, sem dúvida, são ocasionadas por um conjunto especial de circunstâncias, sentimentos, histórias e experiências única e particularmente nossas, como sujeitos individuais. Nossas identidades são, em resumo, formadas culturalmente (HALL, 1997, p. 26-27).

Nesse sentido, e reevocando a ideia de que a modernidade está assentada na noção de fluidez, de descontinuidade, os pressupostos acima mencionados nos permite salientar que - (com relação à formulação de discursos identitários) - o grande conflito que assola o homem moderno gira em torno da capacidade de edificar laços de sociabilidade que liguem sua história individual à história do grupo ao qual se insere, configurando formas de interações que encontrem ressonâncias na vida social. Melhor dizendo, de poder participar ativamente da construção das instâncias de significação onde se exprimem os princípios da vida moral, intelectual e espiritual que informam sua existência. Portanto, cabe aqui uma indagação: que táticas e estratégias o homem moderno pode lançar mão para acessar referenciais simbólicos que lhe permitam formular uma imagem de si e da cultura na qual está imerso?

Para se atribuir uma resposta satisfatória a essa questão, devemos começar enfatizando que, em seu conjunto, tais referenciais são produzidos, preservados e compartilhados por inúmeras esferas da vida social - a família, a escola, a igreja, os sindicatos, o trabalho, entre outras - através das práticas culturais que lhes caracterizam: ritos religiosos; recursos de enunciação da linguagem; maneiras de se alimentar e de decodificar os signos passíveis de leitura, de enterrar seus mortos e manejar suas matérias primas, do uso que faz do corpo e dos caminhos que traçam para se apossarem dos espaços urbanos. Aliado a isso, e por ser uma atividade ligada à reconstrução do vivido (seja este individual ou coletivo), a memória certamente se encontra em posição de destaque neste jogo de trocas simbólicas.

\footnotetext{
${ }^{5}$ Segundo Michel de Certeau (1994), as táticas e as estratégias se referem aos vários mecanismos utilizados por sujeitos comuns para se apropriarem dos espaços e dos insumos culturais neles presentificados através de ações que viabilizam uma produção autônoma de sentido.
} 
Isso porque, o trabalho da memória é essencialmente de elaboração, sendo mais preciso: de reelaboração da experiência de vida humana a partir do reconhecimento e da reatualização de uma lembrança. Dinâmica que só se torna possível através do contato com a realidade presente, uma vez que utilizamos conhecimentos acumulados para lidarmos com situações novas, que se encontram unidas a novas lembranças. Elas, por sua vez, estão associadas à maneira de pensar de tantos outros que fizeram e que ainda fazem parte de nossa história.

Podemos, pois, determinar que a memória é um acúmulo de lembranças? Uma função do passado? Um conhecimento do passado? A organização temporal de um passado individual ou a organização de um passado comum a um número mais ou menos vasto de homens? Uma função ligada à inteligência e ao conhecimento, uma repetição, uma imitação? Certamente que não. Migratória em sua essência, a memória não pode ser considerada como uma evocação literal do passado, mas antes, uma reaproximação, ou melhor, uma recriação do vivido. Sendo assim, a memória está presente em tudo e em todos. Nós somos tudo aquilo que lembramos; nós somos a memória que temos. Para sermos mais explícitos:

A memória não é só pensamento, imaginação e construção social; ela é também uma determinada experiência de vida capaz de transformar outras experiências a partir de resíduos deixados anteriormente. A memória, portanto, excede o escopo da mente humana, do corpo, do aparelho sensitivo e motor e do tempo físico, pois ela é também o resultado de si mesma; ela é objetivada em representações, rituais, textos e comemorações (SANTOS, 2003, p. 25-26).

Analisando com acuidade a definição acima apresentada percebemos que a memória está ligada, em primeiro lugar, a um conjunto de funções psíquicas graças as quais o homem pode atualizar impressões ou informações passadas ou que ele representa como passadas. Contudo, como excede a mente humana, a memória também se alimenta de imagens, sentimentos, ideias e valores que circulam na esfera do social, transfigurando-se em construto coletivo resultante da interação entre indivíduos no presente.

Portanto, partindo da concepção de que a memória é uma faculdade estruturada por indivíduos em interação, que são a um só tempo constituídos e constituintes de sua história, nos tornamos capazes de assinalar que a preservação e o acesso aos insumos mnemônicos se convertem em táticas e estratégias poderosas para que o homem moderno fundamente seus referenciais identitários. Vejamos de maneira mais detalhada como essa relação se inscreve e se estabelece na seção subsequente.

\section{Relações entre memória, esquecimento e identidade social}

O que é a memória? Todo aquele que pretenda elaborar uma análise esclarecedora para essa instigante questão deve começar sua empreitada valendo-se da seguinte prerrogativa: embora se apresente como uma função extremamente elaborada, a memória não existe sem se contrapor ao esquecimento. Isto porque, a construção do discurso simbólico que rege as ações 
humanas no presente só se efetiva a partir dos movimentos intermitentes ao ato de rememorar e de esquecer. Premissa que nos permite apontar que a história humana, tal qual sua ordem social, não se estabelece a partir da sucessão de eventos lineares, mas sim, através da localização de determinada experiência vivenciada no passado, em associação a uma experiência do presente por meio da memória. Razão pela qual nenhuma compreensão da realidade pode ser total, bem como nenhuma interpretação, por mais exemplar que seja, é capaz de abarcar todas as dobras que a memória executa.

Não por acaso, se fôssemos capazes de organizar a história do Ocidente através de grandes capítulos temáticos, certamente um dos mais fascinantes seria aquele dedicado à análise das relações instituídas entre a memória, o esquecimento e a formação dos discursos identitários humanos, visto que, ao comportarem uma ampla gama de sentidos históricos, psico-sociais, filosóficos ou poéticos, tais conceitos se manifestam como esferas de interlocução profícua para lançarmos um rastro de compreensão sobre as coisas dos homens e sobre seus múltiplos processos de interação social.

Nesse sentido, mesmo que à primeira vista memória, esquecimento e identidade formem um triedro contrastante e com ângulos de intersecção aparentemente turvos, suas relações são, de fato, muito próximas. Ou seja, para poder evocar as experiências do passado que respaldam suas ações no presente, cada sujeito utiliza como ponto de referência as lembranças dos outros, norteando seus feitos através de elementos que existem fora dele e que são fixados pela sociedade. São, pois, construções discursivas resultantes da atividade interrelacional entre os sujeitos, e entre os sujeitos e as coisas no presente. Sendo assim, e tendo como ponto de partida esse mosaico de relações, pergunta-se: como funciona a memória humana?

Se recorrermos aos estudos de Agostinho (2000), Benjamin (1980), Bosi (2003; 2004), Halbwachs (1990), Jeudy (1990), Le Goff (2003), Lovisolo (1989), Nora (1993), Pollak (1989; 1992), Santos (1998; 2002; 2003), Silveira (2007), Vernant (1990), Weinrich (2001) e Yates (1986), tornar-se-á claro que existem duas formas de se reevocar uma lembrança (voluntária e involuntariamente) e que esse processo pode ser elaborado tanto individual quanto coletivamente.

Em termos conceituais, a memória voluntária é, segundo Proust (2002), um produto da inteligência que reelabora fatos já passados através de um esforço consciente do sujeito que tenta evocá-los. Esta memória, que depende da nossa vontade, funciona como um simples arquivo, nos fornecendo fatos, datas, números e nomes, mas não as sensações que experimentamos outrora e que não habitam em nossa consciência. Para o autor acima referenciado, tais sensações jazem mais fundo e só são despertadas pela memória involuntária, aquela que não depende de nosso esforço consciente de recordar, que está adormecida em nós e que a um fato qualquer pode fazer emergir a consciência e reencontrar o tempo, bem como recuperar o passado. Tempo esse que não existe mais em nós, mas que continua a viver oculto em um sabor, em um aroma, em um som, em uma dada paisagem. É o que podemos apreender do trecho que se segue:

[...] quando num dia de inverno, chegando eu em casa, minha mãe, vendo-me com frio, propôs que tomasse, contra meus hábitos, um 
pouco de chá. A princípio recusei e, nem sei bem por que, acabei aceitando. Ela então mandou buscar um desses biscoitos curtos e rechonchudos chamados madeleines. E logo, maquinalmente, acabrunhado pelo dia tristonho e a perspectiva de um dia seguinte igualmente sombrio, levei à boca uma colherada de chá onde deixara amolecer um pedaço de madeleine. Mas no mesmo instante em que esse gole, misturado com os farelos do biscoito, tocou meu paladar, estremeci, atento ao que se passara de extraordinário em mim. Invadira-me um prazer delicioso, isolado sem a noção de sua causa. Radicalmente me tornaram indiferentes as vicissitudes de minha vida, inofensivos os seus desastres, ilusória a sua brevidade, da mesma forma como opera o amor, enchendo-me de uma essência preciosa; ou antes, essa essência não estava em mim, ela era eu. Já não me sentia medíocre, contingente, mortal (PROUST, 2002, v. 1, p.51).

Essas sensações, que se tornaram capazes de restabelecer a felicidade do narrador que nos fala, foram trazidas pela memória e por suas doces recordações de uma infância amena e aprazível na companhia de sua mãe. Reminiscências que não foram evocadas pela vontade consciente de seu portador, mas por um estímulo externo que, mesmo aparentando encontrar-se fora de seu domínio e de seu alcance, de alguma forma ligava-se diretamente ao seu passado. Passado que, por sua vez, evoca um processo de reelaboração, cujos matizes estão acentados tanto em critérios individuais, quanto coletivos.

Portanto, essa bela passagem proustiana nos mostra, ainda, que o homem elabora suas memórias de duas maneiras: individual e coletivamente. A primeira parte de uma perspectiva individual, em decorrência dos acontecimentos vividos e interpretados subjetivamente. A segunda se manifesta a partir da constatação de que todo sujeito compartilha com o grupo ao qual pertence acontecimentos e situações que se configuram como experiências fundamentais para a constituição do quadro de referências onde os contornos de sua memória se assentam. Tais fatos são, segundo Pollak:

Acontecimentos dos quais a pessoa nem sempre participou mas que, no imaginário, tomaram tamanho relevo que, no fim das contas, é quase impossível que ela consiga saber se participou ou não. Se formos mais longe, a esses acontecimentos vêm se juntar todos os eventos que não se situam dentro do espaço-tempo de uma pessoa ou de um grupo. É perfeitamente possível que por meio da socialização política, ou da socialização histórica, ocorra um fenômeno de projeção ou identificação com determinado passado, tão forte que podemos falar numa memória quase que herdada (POLLAK, 1992, p. 201).

A memória não se constitui, pois, como uma cópia, um decalque do passado. Isto porque, os acontecimentos, os seres e imagens não se apresentam à memória como formas acabadas ou perfeitamente delineadas. No momento em que são evocadas, durante o ato de recordar, as lembranças ligam-se sempre a 
outros elementos, elementos que, por sua vez, as tornam diferentes. Prerrogativa que nos ajuda a entender que o aspecto labiríntico e sinuoso da memória invalida qualquer certeza ou possibilidade de exatidão. Talvez por isso Pierre Nora ressalte que:

A memória é a vida, sempre carregada por grupos vivos e, nesse sentido, ela está em permanente evolução, aberta à dialética da lembrança e do esquecimento, inconsciente de suas deformações sucessivas, vulnerável a todos os usos e manipulações, susceptível de longas latências e de repentinas revitalizações. A memória é um fenômeno sempre atual, um elo vivido no eterno presente. Porque é afetiva e mágica, a memória não se acomoda a detalhes que a confortam; ela se alimenta de lembranças vagas, telescópicas, globais ou flutuantes, particulares ou simbólicas, sensíveis a todas as transferências, cenas, censuras ou projeções. A memória instala a lembrança no sagrado. A memória emerge de um grupo que ela une, o que quer dizer que há tantas memórias quantos grupos existem; que ela é por natureza, múltipla e desacelerada, coletiva, plural e individualizada. A memória se enraíza no concreto, no gesto, na imagem, no objeto (NORA, 1993, p. 9).

Portanto, mesmo que tenha sofrido transformações de acordo com o olhar de cada pensador ou cultura que Ihe atribuiu um determinado valor interpretativo, essas características são denotadas à memória desde suas primeiras concepções. Sendo mais preciso, desde quando os Gregos da época arcaica fizeram da memória uma deusa: Mnemosine, "testemunha inspirada dos "tempos antigos", da idade heróica e, por isso, da idade das origens" (LE GOFF, 2003, p. 433).

O que implica ressaltar que ao fazer emergir os segredos do passado e se postar como antídoto do esquecimento, a memória se apresenta, desde suas primeiras concepções advindas da tradição grega, como uma função extremamente elaborada que atinge grandes categorias psicológicas como a do tempo e a do eu. Concepções que põem em jogo um conjunto de operações mentais complexas, cujo domínio pressupõe esforço, treinamento e exercício. Entretanto, há o Esquecimento que subjuga a Memória. Letos é o rio cujas águas mágicas fazem ruir os duros contornos da lembrança. Por esta razão, segundo Weinrich:

Nos gregos, Letos é uma divindade feminina que forma um par contrastante com Mnemosine, deusa da memória e mãe das musas. Segundo a genealogia e a teogonia, Lete vem da linhagem da noite (em grego nyx, nox em latim), mas não posso deixar de mencionar o nome de sua mãe. É a Discórdia (em grego, eris, em latim, discordia), o ponto escuro nesse parentesco (WEINRICH, 2001, p. 24).

Elementos de contraste que nos ajudam a demonstrar que a memória não é infalível e que é impossível pensá-la como uma forma perfeita, inteiriça e sem 
furos. Sem a noção de esquecimento não há possibilidade de uma reminiscência ${ }^{6}$. Ao beber as águas do Lete os antigos adquiriam a capacidade de esquecer sua existência anterior e ficavam livres para renascer. Daí as torrentes do rio Lete serem tão importantes para os poetas. Ao narrar as façanhas dos deuses, esses "mestres da verdade" faziam renascer as glórias e infortúnios de sua tradição coletiva, instituindo, preservando e difundindo referenciais comuns de sociabilidade.

Embora circunscrevendo-se na esfera do mito, é importante destacar que essa primeira tentativa de desvendar os segredos da memória traz incutida em seu imaginário coletivo a crença de que os homens são seres sociais porque suas ações (inclusive aquelas ligadas à memória) se norteiam através dos princípios que regem o processo de integração do sujeito com a coletividade onde experimenta um sentimento de pertença. Isto porque, "a memória opera com grande liberdade escolhendo acontecimentos no tempo e no espaço, não arbitrariamente, mas porque se relacionam através de índices comuns. São configurações mais intensas quando sobre elas incide o brilho de um significado coletivo" (BOSI, 2003, p. 31).

Ao dialogarmos com a pensadora acima citada, queremos defender que os sentidos que atribuímos às nossas lembranças são frutos da negociação que diariamente instituímos com o outro. Nessas condições, nossas lembranças do passado:

[...] por mais que pareçam fruto de sentimentos e pensamentos exclusivamente individuais, somente existem como parte de estruturas ou contextos sociais. A lembrança do passado, portanto, não é o ato individual de recordar, mas o resultado de laços de solidariedade, e, como tal, só pode existir porque foi constituída em relação a todo um conjunto de noções e convenções comuns, presentes em pessoas, grupos, lugares, datas, palavras e formas de linguagens das quais nós fazemos ou fizemos parte (SANTOS, 2002, p. 131).

De acordo com tal proposição, e retomando a ideia de que a construção de discursos identitários é um fenômeno que também se produz a partir do diálogo com o outro, os argumentos apresentados por Santos (2002; p. 131) nos ajudam a melhor visualizar as tramas que interconectam os conceitos de memória, esquecimento e identidade. Isto porque, além de serem instâncias de enunciação forjadas socialmente e submetidas a flutuações, transformações e mudanças constantes, eles se constituem como aportes significativos para que os sujeitos modernos esbocem uma tentativa de compreensão das relações que vivenciam na contemporaneidade a partir dos critérios de aceitabilidade, de admissibilidade e de credibilidade que perpassam o universo de cada um deles.

Promulgada essa constatação, cabe-nos aqui levantar mais uma questão: se a memória individual é falha e a identidade do sujeito pós-moderno é

\footnotetext{
${ }^{6}$ Os gregos do período arcaico definiam reminiscência como capacidade de rememorar os eventos e seres que a tradição elaborava. Sendo mais exato, como técnica por meio da qual os iniciados (em especial os poetas) exercitavam seus dons mnemônicos.
} 
caracterizada pela fragmentação, como podemos edificar discursos e esferas sociais de representação coletiva?

Podemos responder a essa pergunta respaldando nossas discussões com mais um indício histórico: da mesma forma como criou sistemas de significação que conferem coerência às relações que estabelece com o mundo e no mundo, 0 homem criou instituições cujo objetivo gira em torno de preservar, administrar e disseminar o repertório simbólico concebido através de sua ação criadora. Nessa perspectiva, as igrejas, as escolas, os sindicatos, os museus, os arquivos e as bibliotecas certamente se posicionam como as de maior visibilidade, visto serem espaços nos quais a cultura mostra sua face universalizante, de tradição e de continuidade, e também onde se vive de maneira concreta as ações e representações de cada um e de todos.

São "lugares de memória" que têm a função de enfrentar o tempo e as incontingências da morte e do esquecimento, bem como colaborar para que uma dada comunidade estruture suas ações em torno de referenciais identitários comuns. Mas o que são e qual a importância dos "lugares de memória" para a constituição e socialização de discursos identitários na contemporaneidade? As bibliotecas públicas podem ser visualizadas como "/ugares de memória"? Discutiremos mais detalhadamente essas duas questões, na próxima seção.

\section{Biblioteca como "lugar de memória" e de identidade social}

Se voltarmos mais uma vez o nosso olhar para as dinâmicas que permeiam os movimentos históricos, vislumbraremos de imediato que os "Lugares de Memória" surgem no exato momento que constatamos a impossibilidade da memória reter voluntariamente a totalidade das experiências humanas, sendo, por isso, necessário criar arquivos; museus; bibliotecas; coleções; santuários; monumentos; organizar celebrações públicas e pronunciar elogios funerários como recurso de articulação social dos insumos simbólicos concebidos para representar coletivamente as ações vivenciadas no mundo e sobre o mundo. Isto porque, segundo NORA (1993, p.13), são estes lugares que "secreta, veste, estabelece, constrói, decreta, mantém pelo artifício e pela vontade uma coletividade fundamentalmente envolvida em sua transformação e sua renovação", ou seja, são eles que, em última instância, viabilizam sua permanência na história e no tempo.

Edificar "lugares de memória" significa, de acordo com essa perspectiva, atribuir-Ihes uma dupla função: a de demonstrar, mesmo que por lampejos, que a constituição do discurso mnemônico é um fenômeno estruturado socialmente e a de reforçar, seja teórica ou factualmente, a tese de que a memória, por mais adjetivos que encontre em seu caminho (voluntária ou involuntária; individual ou coletiva), resiste às reduções impostas pelos enunciados contemporâneos que defendem o fim da história e a desarticulação das interações simbólicas forjadas no nível do social. Todo lugar de memória é, pois, "um lugar duplo; um lugar de excesso, fechado sobre si mesmo, fechado sobre sua identidade; e recolhido sobre seu nome, mas constantemente aberto sobre a extensão de suas signifiçações" (NORA, 1993, p. 27).

É o que acontece com as bibliotecas, especialmente com as públicas, cuja função social está diretamente ligada à missão de preservar, organizar e 
disseminar os elementos culturais e os saberes concebidos pela ação racional dos homens. Enquanto "lugares de memória", as bibliotecas tendem a reafirmar os saberes e a torná-los móveis, traduzíveis, permutáveis. São instituições que nos permitem, por intermédio de seus acervos, acessar as experiências comuns a toda humanidade, bem como as razões e os intentos de cada um de seus usuários em particular. Neste sentido, toda biblioteca é, ao menos à primeira vista:

Lugar da memória nacional, espaço da conservação do patrimônio intelectual, literário e artístico, uma biblioteca é também o teatro de uma alquimia complexa em que, sob o efeito da leitura, da escrita e de sua interação, se liberam as forças, os movimentos do pensamento. É um lugar de diálogo com o passado, de criação e inovação, e a conservação só tem sentido como fermento dos saberes e motor do conhecimento, a serviço da coletividade inteira (JACOB, 2000, p. 9).

Sendo assim, a razão para lançarmos um olhar sobre a história das bibliotecas e de suas coleções liga-se à dificuldade que teríamos para compreender e transformar o mundo onde habitamos sem os elementos materiais e imateriais que nelas se preservam. Elas são a memória do mundo: todos os conhecimentos humanos em um só lugar. Isto é, aquilo que o conhecimento significa para o homem é o que a biblioteca pretende conservar, seja este "o sopro de Deus, as Musas, a morada do Bom e do Belo, os ventos uivantes do comércio, ou uma mistura confusa de todas estas coisas - será aquilo que a biblioteca é templo". (BATTLES, 2003, p.16). De acordo com esta proposição, biblioteca serve aqui para figurar um lugar demarcado:

Tão amplo e completo na sua dimensão de abarcar todo o conhecimento, de forma tão extensa e exaustiva, que não haveria outro lugar de interlocução, a não ser o seu próprio espaço sígnico e material, seus estoques e significados: textos sem contexto, a biblioteca total fabulada por Borges, que não remeteria a outro lugar, a não ser a ela própria (MARTELETO, 1996, p. 241).

Implicações que nos permitem ressaltar que se a memória é capaz de inspirar, recuperar a graça do tempo, distender conceitos duros, devolver o entusiasmo pelo que era caro e se perdeu, redimir o sagrado e devolver não simplesmente o passado, mas o passado que prometia, as bibliotecas, enquanto lugares místicos que congregam a amplitude dos saberes concebidos pela humanidade, se configuram, em ampla medida, como o espaço onde o homem, sua herança cultural, seu patrimônio simbólico, sua tradição e sua memória coletiva se mesclam na tentativa de superar o esquecimento e se preservar futuro adiante. Característica que lhe confere o status de lugar de continuidade e de preservação da história em tempos e espaços específicos.

Argumento que se fortalece quando lembramos que a história das bibliotecas acaba por se converter na história daquilo que uma sociedade decide preservar e transmitir ao longo de seu continum histórico. Através da estrutura caleidoscópica de seus acervos, cada uma dessas instituições oferece ao lugar 
onde se insere uma espécie de espelho, que reflete os interesses e fraquezas de seus interlocutores, bem como a maravilhosa pluralidade identitária que conformam os estratos vitais de uma nação. Em outras palavras, são elas que generosamente oferecem "uma imagem negociável daquele mundo real que gentilmente permite que o concebamos" (MANGUEL, 2006, p. 265).

Portanto, seja como espaço físico, como símbolo de uma ordem cósmica ou social ou como forma visível da razão humana, as bibliotecas são lugares que guardam histórias e despertam o fascínio e o encantamento. Lugares onde tais elementos se transmutam, perturbando e excitando fantasias, irmanando o sonho com a ação, além de provocarem medo e instigarem reações. São lugares de confrontos, de sonhos e de pesadelos. Espaços onde se inscrevem as angústias e as esperanças de uma época, bem como suas contradições e confusões. São, ainda:

Lugares mistos, híbridos e mutantes, intimamente enlaçados de vida e de morte, de tempo e de eternidade; numa espiritual do coletivo e do individual, do prosaico e do sagrado, do imóvel e do móvel. Anéis de Moebius enrolados sobre si mesmos. Porque, se é verdade que a razão fundamental de ser de um lugar de memória é parar o tempo, é bloquear o trabalho do esquecimento, fixar um estado de coisas, imortalizar a morte, materializar o imaterial para prender o máximo de sentido num mínimo de sinais, é claro, e é isso que os torna apaixonantes: que os lugares de memória só vivem de sua aptidão para a metamorfose, no incessante ressaltar de seus significados e no silvado imprevisível de suas ramificações (NORA, 1993, p. 22).

Características que não são exclusivas das bibliotecas imperiais do mundo antigo ou daquelas ligadas às grandes ordens monásticas da Idade Média, visto que o adjetivo público, que contemporaneamente se juntou ao nome da biblioteca, serviu para reforçar a ideia de que elas são instituições sociais sempre em evolução, que influenciam e são influenciadas pela estrutura social que as circundam, refletindo e contribuindo para o seu desenvolvimento através da coleta, organização e disseminação dos produtos culturais, na produção e administração do conhecimento registrado, além da garantia de livre acesso a todos aqueles que queiram utilizá-los.

Isto porque, enquanto centros locais de informação, as bibliotecas públicas possuem como missão política e civilizadora a tarefa de colaborar para a difusão e visibilidade dos vários signos que se originam de nossas práticas culturais, sem se levar em consideração critérios ligados à etnia, crença religiosa, condição financeira, questões sexuais ou políticas, a fim de colocá-los a serviço de toda uma coletividade. Missão que, se analisada com a acuidade que merece, nos permite demonstrar que as bibliotecas públicas, tal qual outros "lugares de memória", se apresentam como palcos que encenam a dramaturgia da sociedade que as acolhe e que, em virtude disso, "a identidade de uma sociedade ou nação [pode sim] ser espelhada por uma biblioteca, por uma reunião de títulos que, em termos práticos ou simbólicos, faça as vezes de definição coletiva" (MANGUEL, 2006, p. 241). 
De acordo com esta perspectiva, podemos responder às questões levantadas ao final da última seção, caracterizando as bibliotecas públicas como lugares de continuidade; espaços permeados por tensões contraditórias, mas que estão abertas ao mundo das realidades e das ideias. Construtos privilegiados do saber onde, por intermédio da materialidade de suas coleções, nossa tradição, nossa memória coletiva e nosso patrimônio cultural se mesclam para urdirem o tecido no qual aquilo que chamamos de identidade se constitui, se nutre e se valoriza. Razão pela qual sua história se converte na história daquilo que uma sociedade pretende transmitir; nos conhecimentos que decide conservar; na necessidade de seu esquecimento para posterior recuperação, mas também, na reevocação e reutilização destes a partir do rememorar. Traçamos mais algumas considerações sobre a efetividade dessas proposições no tópico seguinte.

\section{Considerações finais}

Em um de seus inúmeros momentos de intensa criação, Jorge Luis Borges nos conta que o mesmo homem que edificou a grande muralha da China foi também aquele que mandou queimar todos os livros anteriores a ele. Che Huangti, o Primeiro Imperador, desejoso de que a história de seu povo começasse por ele, erigiu a muralha porque esta era sua defesa e queimou os livros porque estes eram invocados para a celebração do passado. Talvez para esse homem "a muralha no espaço e o incêndio no tempo foram barreiras mágicas destinadas a deter a morte" (BORGES, 1999, p. 10).

Ao exigir que uma sociedade tão tradicional quanto a dos chineses abandonasse seu passado, sua história, talvez Che Huang-ti acreditasse que a imortalidade estaria intrínseca a seu ato e que a corrupção não poderia entrar em um orbe fechado, sonhando, assim, fundar uma dinastia imortal. Contudo, destruir a história anterior a si não significou, necessariamente, um ato de arrogância ou de desonra para com a tradição de seu país, visto que, como aponta o próprio Borges (1999, p.10-11):

Talvez a muralha fosse uma metáfora, talvez Che Huang-ti tenha condenado aqueles que adoravam o passado a uma obra tão vasta quanto o passado, tão néscia e tão inútil. Talvez a muralha fosse um desafio e Che Huang-ti tenha pensado: "Os homens amam o passado, e contra esse amor nada posso nem podem meus carrascos, mas um dia há de viver um homem que sinta como eu, e ele destruirá minha muralha, como eu destruí os livros, e ele apagará minha memória e será minha sombra e meu espelho, e não o saberá". Talvez Che Huang-ti tenha amuralhado o império porque sabia que este era precário e destruído os livros por entender que eram sagrados, ou seja, livros que ensinam o que ensina o universo inteiro ou a consciência de cada homem (BORGES, 1999, p.10-11).

Desta forma, a oposição entre edificar e destruir traz consigo o seguinte paradoxo: as coisas e as ações humanas adquirem sentido em si mesmas, mas 
também, e sobretudo, através das interpretações que o indivíduo e a coletividade Ihes impõe. Portanto, talvez a grande lição que podemos apreender dos feitos de Che Huang-ti seja aquela que demarca que a história se constrói a partir da passagem contínua do tempo, no qual seu incessante fluir, furtivamente, proíbe o presente de permanecer para sempre.

Diante da metáfora que o nome e os feitos míticos de Che Huang-ti encerra, como não nos lembrar da laboriosa minúcia com que a ficção borgiana recompõe as ruínas daquelas essências que perpassam a literatura dos filósofos platônicos, cristãos, cabalistas e cientistas de várias épocas até a disposição dos livros em galerias hexagonais da Biblioteca de Babel?

De fato, uma das imagens clássicas da memória apresentada nos textos borgianos é a biblioteca, com suas galerias, livros, enciclopédias avançando com e no tempo e mapeando os saberes do mundo. A biblioteca feita da mesma matéria que são feitos os sonhos. Uma Babel inscrita na memória dos tempos, cujas medidas perturbadoras não contêm apenas todos os livros que existem, mas também todos os que se pode imaginar para o futuro. Isto porque, segundo 0 próprio Borges:

Não há, na vasta Biblioteca, dois livros idênticos". Dessas premissas incontrovertíveis deduziu que a Biblioteca é total e que suas prateleiras registram todas as possíveis combinações dos vinte e tantos símbolos ortográficos (número, ainda que vastíssimo, não infinito), ou seja, tudo o que é dado expressar: em todos os idiomas (BORGES, 1998, p. 518).

Enquanto labirinto terreno e espiritual, a Babel formulada por Borges prefigura um universo de regras próprias, cujo fim último é traduzir as do universo informe ao seu redor. Neste sentido, as formulações poéticas presentes em seu texto têm o objetivo de demarcar que:

A biblioteca existe $a b$ aeterno. Dessa verdade cujo corolário imediato é a eternidade futura do mundo, nenhuma mente razoável pode duvidar. O homem, o imperfeito bibliotecário, pode ser obra do acaso ou dos demiurgos malévolos; o universo, com seu elegante provimento de prateleiras, de tomos enigmáticos, de infatigáveis escadas para o viajante e de latrinas para o bibliotecário sentado, somente pode ser obra de um deus. Para perceber a distância que há entre o divino e o humano, basta comparar estes rudes símbolos trêmulos que minha falível mão garatuja na capa de um livro, com as letras orgânicas do interior; pontuais, delicadas, negríssimas, inimitavelmente simétricas (BORGES, 1998, p.517).

Essas dobras do tempo e da memória que os textos borgianos engendram, nos faz, seus leitores, perguntar sobre a realidade das coisas: o que é o mundo? $O$ que é o homem e seus conhecimentos? Através dos paradoxos, das enciclopédias e da dança dos tigres nos deparamos com o absurdo do mundo. Possuir o engenho da memória dos tempos é sonhar o mundo. 
Dialogando com esta proposição, percebemos que o traçado poético desse homem apaixonado pelos livros, nos auxilia a formular argumentos que trazem ancorados, em seu bojo, evidências de que as bibliotecas (inclusive as públicas) representam a metáfora da acumulação total: todo o conhecimento humano em um só lugar, bem como seu sonho de perpetuar-se no tempo, mesmo agora quando descobrimos que:

[...] finalmente dotados de signos, os seres humanos perdem as próprias recordações pessoais, às quais tendem a abdicar. Assim, mais do que nunca, a memória parece encerrar em si um segredo: o armazém da realidade transforma-se numa complexa caverna pintada, onde a entrada não garante necessariamente a saída, e o que foi ciosamente mantido nas salas das lembranças revela-se no fim um "espelho dos enganos"; e o passado esvai-se lento, porém dolorosamente, no tempo que em vão tentamos dominar [...]. (COLOMBO, 1991, p.20-50).

Dominar o tempo e o esquecimento, por mais fluidos e abstratos que estes conceitos possam parecer, sempre foi o grande sonho humano. É por esse motivo que aqui:

A biblioteca parece assim ser uma espécie de Penélope que tece os fios da teia do tempo e do conhecimento, e à noite a desfaz pelo silêncio, para recomeçar no outro dia o mesmo trabalho. Palavra efêmera, conhecimento efêmero. A teia, o tecido é esse grande discurso que ela encara no que é manifesto, e naquilo que se mostra, e no que é subterrâneo, latente; precisa e se quer desvelado (CASA NOVA, 1990, p. 136).

Desvelar os segredos de uma biblioteca significa apreender que em seus acervos estão preservados o conjunto dos elementos históricos que informam os sujeitos sobre seu passado, e que esses lhe conferem a possibilidade de projetar uma explicação para o presente, de divagar acerca do futuro. Enquanto produto da ação racional e relacional dos homens, elas se portam como pouso seguro para todos os delírios, sonhos, paixões, aventuras e desventuras da alma humana.

Portanto, se nosso objetivo inicial era investigar qual a participação das bibliotecas púbicas no processo de constituição, preservação e difusão de referenciais identitários na contemporaneidade, ao fim destas páginas, penso ter demonstrado que tais instituições são sim um pólo importante para a constituição do tecido social onde aquilo que chamamos de identidade encontra solo profícuo para nutrir-se e valorizar-se. Sendo mais explícito, os argumentos aqui apresentados evidenciam que as bibliotecas públicas, através de sua missão e das relações que mantém com a memória e com o esquecimento, encontram-se permeadas pelas mais diversas experiências humanas. Experiências que, em última instância, oferecem pontos de referências para as ações que dizem nosso lugar no mundo. Ou seja, através da estrutura caleidoscópica de seus acervos, cada uma dessas instituições oferece ao lugar onde se insere uma espécie de espelho que reflete os interesses e as fraquezas de seus interlocutores, bem como 
a maravilhosa pluralidade identitária que constitui os estratos vitais das mais diversas tradições coletivas.

\section{Referências}

AGOSTINHO, S. Confissões. Rio de Janeiro: Nova Cultural, 2000. (Coleção os Pensadores).

BATTLES, M. A conturbada história das bibliotecas. São Paulo: Planeta, 2003.

BENJAMIN, W. O narrador: observações sobre a obra de Nikolai Leskov. In: BENJAMIN, W. et al. Os pensadores. São Paulo: Abril Cultural, 1980. p. 57-74.

BORGES, J. L. A biblioteca de babel. In: BORGES, J. L. Ficções. Porto Alegre: Globo, 1998. p. 516-523. (Obras Completas, 1).

A muralha e os livros. In: BORGES, J. L. Outras inquisições. Porto Alegre: Globo, 1999. p. 9-11. (Obras Completas, 2).

BOSI, E. A substância social da memória. In: BOSI, E. O tempo vivo da memória: ensaios de psicologia social. 2 ed. São Paulo: Ateliê, 2003. p.13-48.

Memória e sociedade: lembrança de velhos. 11 ed. São Paulo: Companhia das Letras, 2004.

CASA NOVA, V. Biblioteca: uma leitura semiológica. R. Esc. Bibliotecon. UFMG, Belo Horizonte, v. 19, n. especial, p.130-137, mar. 1990.

CERTEAU, M. A invenção do cotidiano. Petrópolis: Vozes, 1994. 2 v.

COLOMBO, F. Os arquivos imperfeitos: memória social e cultura eletrônica. São Paulo: Perspectiva, 1991.

DARNTON, Robert. O poder das bibliotecas. Folha de São Paulo, São Paulo, 15/04/2001, Caderno Mais, p. 4-7.

FRANÇA, V. R. V. Discurso de identidade, discurso de alteridade: a fala do outro. In: GUIMARÃES, C. et al. Imagens do Brasil: modos de ver, modos de conviver. Belo Horizonte: Autêntica, 2002. p.27-43.

GIDDENS, 1990 apud HALL, S. A diversidade cultural na pós-modernidade. 5 ed. Rio de Janeiro: DP\&A, 2001.

GARCÍA CANCLINI, Néstor. Diferentes, desiguais e desconectados: mapas da interculturalidade. Rio de Janeiro: UFRJ, 2005.

GUIMARÃES, C. et al. Imagens do Brasil: modos de ver, modos de conviver. Belo Horizonte: Autêntica, 2002.

HALBWACHS, M. A memória coletiva. São Paulo: Vértice / Editora Revista dos Tribunais, 1990. (Biblioteca Vértice de sociologia e política).

HALL, S. A centralidade da cultura: notas sobre as revoluções culturais no nosso tempo. Educação \& Realidade, Rio Grande do Sul, v. 22, n. 2, p.15-46, jul./dez. 1997.

2001.

A diversidade cultural na pós-modernidade. 5 ed. Rio de Janeiro: DP\&A, 
HALL, Stuart. Da diáspora: identidades e mediações culturais. Belo Horizonte: Editora UFMG ; Brasília: Representação da UNESCO no Brasil, 2003.

JACOB, C. Ler para escrever: navegações alexandrinas. In: BARATIN, M.; JACOB, C. (Orgs.). O poder das bibliotecas: a memória dos livros no ocidente. Rio de Janeiro: UFRJ, 2000. p. 45-73.

JACOB, Christian. Prefácio. In: BARATIN, Marc; JACOB, Christian (Orgs.). O poder das bibliotecas: a memória dos livros no ocidente. Rio de Janeiro: UFRJ, 2000, p.9-17.

JEUDY, H. Memórias do social. Rio de Janeiro: Forense Universitária, 1990.

LATOUR, Bruno. Redes que a razão desconhece: laboratórios, bibliotecas, coleções. In: BARATIN, Marc; JACOB, Christian (Orgs.). O poder das bibliotecas: a memória dos livros no ocidente. Rio de Janeiro: UFRJ, 2000, p.21-44.

LE GOFF, J. Memória. In: LE GOFF, J. História e memória. 5 ed. Campinas: Editora da UNICAMP, 2003. p. 419-476.

LOVISOLO, H. A memória e a formação dos homens. Estudos históricos, Rio de Janeiro, v. 2, n. 3, p.16-28, 1989.

MANGUEL, A. A biblioteca à noite. São Paulo: Companhia das Letras, 2006.

MARTELETO, R. M. "Lugares dos signos" e contextos de informação: a biblioteca como metáfora dos conhecimentos modernos. R. Bibliotecon., Brasília, v. 20, n. 2, p. 241-246, jul./dez. de 1996.

MÜLLER, Suzana P. M. Biblioteca e sociedade: evolução da interpretação das funções e papéis da biblioteca. R. Esc. Bibliotecon. UFMG. Belo Horizonte, 13(1): 7-54, mar. 1984.

NÓBREGA, Nanci Gonçalves da. Acervos como memória do mundo (e sobre suas dinamização). INFORMARE: Cad. Prog. Pós-Grad. Ci. Inf. Rio de Janeiro, v.5, n.1, p.59-76, jan./jun. 1999.

NORA, P. Entre memória e história: a problemática dos lugares. Proj. História, São Paulo, v.10, p.7-28, dez. 1993.

POLLAK, M. Memória e identidade social. Estudos históricos, Rio de Janeiro, v. 5, n. 10, p. 200-212, 1992.

POLLAK, M. Memória, esquecimento, silêncio. Estudos históricos, Rio de Janeiro, v. 2, n. 3, p.3-15, 1989.

PROUST, M. Em busca do tempo perdido. Rio de Janeiro: Ediouro, 2002. (Obra completa, 3 v.).

SANTOS, M. S. Memória coletiva e teoria social. São Paulo: AnnaBlume, 2003.

- O pesadelo da amnésia coletiva: um estudo sobre os conceitos de memória, tradição e traços do passado. Cadernos de sociomuseologia, Portugal, n.19, p.121-150, 2002.

- Sobre a autonomia das novas identidades coletivas: alguns problemas teóricos. RBCS, v. 13, n. 38, p.151-165, out. 1998. 
SERRAI, Alfredo. História da biblioteca como evolução de uma idéia e de um sistema. R. Esc. Bibliotecon. UFMG, Belo Horizonte, 4(2) : 141-161, set. 1975.

SILVEIRA, F. J. N. Biblioteca como lugar de práticas culturais: uma discussão a partir dos currículos de Biblioteconomia no Brasil. 2007. 246f. Dissertação (Mestrado em Ciência da Informação) - Escola de Ciência da Informação da Universidade Federal de Minas Gerais, Belo Horizonte, 2007.

VERNANT, J. P. Aspectos míticos da memória e do tempo. In: VERNANT, J. P. Mito e pensamento entre os gregos: estudo de psicologia histórica. Rio de Janeiro: Paz e Terra, 1990. p.105-131.

WEINRICH, H. Lete: arte e crítica do esquecimento. Rio de Janeiro: Civilização Brasileira, 2001.

YATES, F. A. El arte de la memória. Madrid: Taurus, 1986. 